\title{
THE EFFECT OF ORGANIZATIONAL CULTURE, QUALITY OF HUMAN RESOURCES, AND THE MOTIVATION TO THE EMPLOYEES PERFORMANCE IN THE CORRECTIONAL INSTITUTION CLASS IIA OF BATAM WITH THE WORK DISCIPLINE OF INTERVENING
}

\author{
William Handoko Gotama1, Bambang Satriawan ${ }^{2}$, Indrayani ${ }^{3}$, Muamkar Khaddafi ${ }^{4}$ \\ 1,2,3 Faculty of Economics, Department of Management, University of Batam \\ ${ }^{4}$ Fakultas Ekonomi, Universitas Malikussaleh Lhokseumawe \\ E-mail: ${ }^{1)}$ setiawan.bks099@gmail.com
}

\begin{abstract}
The purpose of this research is to analyse the influence of organizational culture variables, human resource quality and performance motivation against work discipline as a intervening variable. The research object was conducted at the Correctional Institution class IIA of Batam City. The purpose of this research is to know the influence of organizational culture to employee performance, influence of human resource quality to employee performance, influence of work discipline on employee performance, organizational culture influence, human resource quality and motivation to employee performance through work discipline, as well as knowing greater where direct influence than indirect influence between organizational culture to performance through work discipline, quality of human resources to performance through working discipline and motivation to performance through work discipline. Respondents in this study amounted to 30 employees and the analytical models used in this study were descriptive analysis, and multiple linear regression analyses with the SPSS for Windows 20.0 program. The results of this study show that organizational culture has a positive and significant influence on employee work discipline. The quality of human resources has a positive and insignificant effect on employee work discipline. Motivation has a negative and insignificant effect on employee work discipline. Organizational culture has a positive and significant effect on employee performance. The quality of human resources has a negative and insignificant effect on employee performance. Human motivation has a positive and insignificant effect on employee performance. Work discipline has a negative and insignificant effect on employee performance.
\end{abstract}

Keywords : Organizational Culture, Quality Of Human Resources, Motivation, Employees Performance And Work Discipline

\section{INTRODUCTION}

\subsection{Background}

Employees are an important asset in a company, without them how difficult it is for the company to achieve its goals, they are the ones who determine the back and forth of a company, by having skilled workers with high motivation the company has very expensive assets, because basically humans are subjects and development object which is a very important factor, especially improving the quality of human resources is a top priority. Performance is an important thing that must be achieved by every company including the PT Pertamina Batam Branch Office, because performance is a reflection of the company's ability to manage and allocate its employees. PT Pertamina is an oil and gas company owned by the Government of Indonesia (National Oil Company), which was established on December 10, 1957 under the name PT P 1961. This 


\section{THE EFFECT OF ORGANIZATIONAL CULTURE, QUALITY OF HUMAN RESOURCES, AND THE MOTIVATION TO THE EMPLOYEES PERFORMANCE IN THE CORRECTIONAL INSTITUTION CLASS IIA OF BATAM WITH THE WORK DISCIPLINE OF INTERVENING} DOI: https://doi.org/10.54443/ijset.v1i2.14

company changed its name to PN P and merged with PN Pertamina in 1 ermina. In and after 968 its name changed to PT Pertamina.

Pertamina (PER PT Pertamina EP is a subsidiary of PT SERO) which is engaged in the upstream sector, its business fields are business activities in the upstream sector of the oil and gas business, including exploration and exploitation, as well as other supporting business activities that directly or indirectly support main business activities. To be able to carry out their duties properly, employee coaching is directed at improving the quality of human resources so that they have attitudes and behaviors that are based on dedication, honesty, professionalism, responsibility, discipline, work ethic, organizational commitment and authority so that they can provide services according to the demands of community development. According to Robbins (2006: 170), to get good performance and increased work results in a work organization, employees must meet the requirements or have basic skills and abilities. Work ethic is a set of positive work behaviors rooted in strong cooperation, fundamental beliefs, accompanied by a total commitment to an integral work paradigm. A high work ethic should be owned by every employee because every organization really needs hard work and high commitment from every employee, otherwise the organization will find it difficult to develop, and win the competition in seizing its market share.

Every organization that always wants to advance, will involve members for its performance, including each organization must have a work ethic. Individuals or community groups can be stated to have a high work ethic. The work ethic possessed by a person or community group will be a source of motivation for their actions. Given the importance of human resources that include roles, management, as well as employee empowerment is needed to spur employee morale, companies must meet several criteria through the application of appropriate human resource management concepts and techniques, one of which is through the provision of rewards. Givingrewards to everyone must be in accordance with their rights and obligations. It should be emphasized here that rewards are not only measured in material terms, but are also influenced by interactions between humans and the organizational environment, at certain times humans are stimulated by economic benefits (economic rewards). The more often the employee is rewarded for a good action taken, the greater the employee will repeat the good action.

Companies must meet several criteria through the application of appropriate human resource management concepts and techniques, one of which is through the provision of rewards. Giving rewards to everyone must be in accordance with their rights and obligations. It should be emphasized here that rewards are not only measured in material terms, but are also influenced by interactions between humans and the organizational environment, at certain times humans are stimulated by economic benefits (economic rewards). The more often the employee is rewarded for a good action taken, the greater the employee will repeat the good action.

Companies must meet several criteria through the application of appropriate human resource management concepts and techniques, one of which is through the provision of rewards. Giving rewards to everyone must be in accordance with their rights and obligations. It should be emphasized here that rewards are not only measured in material terms, but are also influenced by interactions between humans and the organizational environment, at certain times humans are stimulated by economic benefits (economic rewards). The more often the employee is rewarded for a good action taken, the greater the employee will repeat the good action. It shouldbe emphasized here that rewards are not only measured in material terms, but are also influenced by interactions between humans and the organizational environment, at certain times humans are stimulated by economic benefits (economic rewards). 


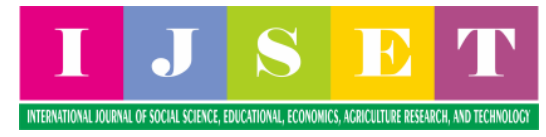

The more often the employee is rewarded for a good action taken, the greater the employee will repeat the good action. It should be emphasized here that rewards are not only measured in material terms, but are also influencedby interactions between humans and the organizational environment, at certain times humans are stimulated by economic benefits (economic rewards). The more often the employee is rewarded for a good action taken, the greater the employee will repeat the good action. Rewards very important in motivating employee performance. Because through rewards, employees will become more qualified and responsible for the tasks given. Motivating employees will improve their performance so that they can spur employees to improve work quality.

\subsection{Literature review}

\section{Work Motivation}

Human resources play a very important role, human resources are seen as the main driving factor in determining the success of an organization. Encouraging employee motivation must be done to encourage the achievement of good performance. Motivationis the process of giving motivation to work for employees so that they want to work for the achievement of organizational goals effectively and efficiently. Increasing motivationis carried out by meeting employee needs. Fulfillment of all needs or wants and expectations will result in employees being satisfied, and employees with high levels of satisfaction will automatically improve their performance. Employees in an organization can be motivated by providing what their needs and wants are. However, giving work motivation can be difficult because what is considered important for someone is not necessarily important for others. In the context of work, motivation is one of the important factors in encouraging an employee to work.

Robbins (1994: 99) argues that motivation isa process of directing and persistence of each individual with a high level of intensity to increase an effort to achieve goals. We can define this motivation as an impetus to increaseefforts in achieving organizational goals, within the limits of the ability to provide satisfaction with one's needs. Argues that motivation is a process of directing and persistence of each individual with a high level of intensity to increase an effort to achieve goals. We can define this motivation as an impetus to increase efforts in achieving organizational goals, within the limits of the ability to provide satisfaction with one's needs.

Argues that motivation is a process of directing and persistence of each individual with a high level of intensity to increase an effort to achieve goals. We can define this motivation as an impetus to increase efforts in achieving organizational goals, within the limits of the ability to provide satisfaction with one's needs. Motivation is a process of directing and persistence of each individual with a high level of intensity to increase an effort to achieve goals. We can define this motivation as an impetus to increase efforts in achieving organizational goals, within the limits of the ability to provide satisfaction with one's needs. Motivation will influence individual attitudes and behavior at work. Every human being certainly has a basic reason, why someone is willing to do a certain type of activity or job, why one person works more actively, while the other person works normally. Work motivation theory studies what motivates a person to work. The strength and weakness of work motivation determine the level of employee performance. This means that the higher the employee's motivation, the higher the employee's performance and vice versa, the lower the employee's motivation, the lower the employee's performance.

\section{Work ethic}

Work ethic is an attitude, viewpoint, habit, characteristics or characteristics regarding the way a person, a group or a nation has worked (Dodi, et al, 2013). Work ethic is the spirit of work 


\section{THE EFFECT OF ORGANIZATIONAL CULTURE, QUALITY OF HUMAN RESOURCES, AND THE MOTIVATION TO THE EMPLOYEES PERFORMANCE IN THE CORRECTIONAL INSTITUTION CLASS IIA OF BATAM WITH THE WORK DISCIPLINE OF INTERVENING} DOI: https://doi.org/10.54443/ijset.v1i2.14

that is seen in the way a person responds to work, the motivation behind doing a job (Fadillah, 2010). The existence of Human Resources (HR) in a company plays a very important role in supporting and demonstrating the company's activities. The potential that exists in every human resource must be utilized properly, so that it can provide maximum results. The success of a company in achieving its goals does not only depend on existing facilities and infrastructure but also depends on the performance of its employees.

Work ethic is an attitude towards work, so that a good work ethic will also result in good performance, of course, will have a significant effect on the progress of the institution / agency where you work Work ethic is very dominant for a person's maximum work success, in the sense that the higher the employee's work ethic, the higher the employee's performance. Work ethic is the spirit and mental attitude of a person or group of people as long as there is moral pressure in it. It can be said that work ethic is a person's perspective in responding, doing and acting at work, with a willingness and attention to the values and rules that apply in an organization, institution or company so that work can be carried out properly. (Tebba, 2003:1) The ability of employees to build a work ethic is a basic attitude towards an employee and work behavior based on mental awareness, confidence accompanied by full commitment to the work activities they do as a whole. Furthermore, these attitudes and views will provide an assessment of work, both high and low assessments, attitudes in carrying out work, both earnest attitude, and work attitudes from being finished. In connection with the existence of an employee as part of an organization, work ethic means mobilizing all of the employee's potential as part of the organization to achieve goals (Sutisna, 2012).

The characteristics of someone who has a high work ethic according to Darodjat are: (1). Have work motivation, namely motivation within and from outside the individual; (2). Has a future orientation; (3). Morality is an attitude of seriousness at work; (4). Hard work and respect for time; (5). Discipline at work, be responsible; (6). Save and simple. (7). Diligent and tenacious. (Darodjat, 2015) Indicators that can be used to measure work ethic include: (1) Hard work, that at work you have a hangover nature to achieve the goals you want to achieve. Can make use of optimal time so that sometimes they do not recognize the time, distance and difficulties being faced; (2) Discipline, as an attitude of respect, respect obedience and obedience to the applicable regulations, both written and unwritten and being able to carry them out and not avoid receiving sanctions if they violate the duties and authorities given to them; (3). Honest, honesty is the ability of an employee to carry out his job according to predetermined rules; (4) Responsibility, namely to provide the assumption that the work done is something that must be done with diligence and sincerity; (4) Diligent, creating personal habits of employees to maintain and improve\%). That have been achieved. Being diligent at work means developing positive habits at work. What is good must be in tip-top shape at all times; (5) Diligent, means diligent, hard-hearted, and earnest (working, studying, trying, etc.). People who are diligent are people who work regularly, are able to withstand boredom / boredom, and want to learn from mistakes (other people and themselves) in the past so they don't happen again. (Salamun et al., 1995) Individuals or groups of people who have a low work ethic will be shown the opposite characteristics, namely; (1). Work is felt as a self-burdening thing; (2). Not even appreciating the work of human beings; (3). Work is seen as an obstacle to obtaining pleasure; (4). Work is done as a form of compulsion. Work is lived only as a form of routine life. (Kusnan, 2004) Increasing work ethic is the concern of every company, each individual has a different level according to the value system they have that applies to them. The higher the work ethic of the employee, the higher the employee's performance. Performance is a 


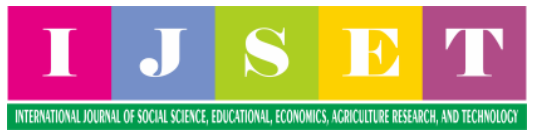

concrete, observable, and measurable work result. So that performance is the result of work achieved by employees in carrying out tasks based on predetermined size and time. (Irawan, 2000: 588)

\section{Rewards}

According to the language of the word reward means a form of reward or remuneration given to a person or group for having behaved well, performing an advantage or achievement, making a contribution, or successfully carrying out the assigned task according to the set target. Whereas in the complete dictionary of psychology reward is any stimulant, situation or oral statement that can produce satisfaction or increase the likelihood of an action. Rewards are rewards, prizes, awards or rewards that aim to make someone more active in his efforts to improveor enhance the performance that has been achieved. Reward is an incentive that links pay on the basis of being able to increase employee productivity in order to achieve a competitive advantage. Rewards given to employees will have a significant effect on performance. In other words, the rewards given to employees will motivate employees to improve employee performance. Can be concluded that, reward is positive feedback givenby the company for the achievements made by employees. Reward or award is a form of appreciation for a certain achievement given, both by and from individuals or an institutionwhich is usually given in the form of a material or greeting. Rewards are also called intrinsic rewards, namely rewards that are part of the work itself, these rewards include a sense of completion, achievement, autonomy and growth, meaning that the ability to start or complete a work project is important for a number of individuals. Because reward is one of the motivation to work in doing work, there are three basic human motivations, namely: the need for power, the need for affiliation and the need for achievement. Because the need for achievement encourages someone to develop creativity and actualize the ability to achieve maximum achievement. Someone realizes that someone with high achievement will get great rewards. The need for power and affiliation encourages people to be more developed because basically humans want to be more powerful, want to be respected and feel important.

\section{Employee Performance}

Employee performance is the result of a certain planned work process at the time and place of the employee and the organization concerned. Performance is a set of results that are achieved and refers to the achievement and implementation of a job requested. Performance to achieve the organization's functioning effectively and in accordance with organizational goals, the organization must have good employee performance, namely by carrying out its duties in a reliable manner. From some expert opinions, it can be concluded that employee performance is the result of work done by someone in an organization in order to achieve the desired goals of an organization and minimize losses. Employee performance is the quality and quantity of work achieved by an employee in carrying out his duties in accordance with the responsibilities given to him based on job requirements, which includes behavior that comes from oneself, namely mental (thought) and physical effort, which can be assessed separately. of the work. Bernardin and Russel (1993: 383) explain, there are six dimensions in assessing employee performance, namely:

\section{Quality}

The extent to which the process or results in carrying out activities in an ideal way, in accordance with the ideal way of carrying out activities or activities that fulfill the intended objectives.

International Journal of Social Science, Educational, Economics, Agriculture Research, and Technology (IJSET) 
THE EFFECT OF ORGANIZATIONAL CULTURE, QUALITY OF HUMAN RESOURCES, AND THE MOTIVATION TO THE EMPLOYEES PERFORMANCE IN THE CORRECTIONAL INSTITUTION CLASS IIA OF BATAM WITH THE WORK DISCIPLINE OF INTERVENING DOI: https://doi.org/10.54443/ijset.v1i2.14

\section{IMPLEMENTATION METHOD}

\section{Population}

Population is a generalization area consisting of: objects/subjects that have certain qualities and characteristics that are applied by researchers to study and then draw conclusions (Sugiyono, 2007). Population is not only people, but also objects and other natural objects. Population is also not just the number that is in the object/subject being studied, but includes all the characteristics/properties possessed by the object/subject under study. The populationin this study was the PT Pertamina Batam Branch Office.

\section{Samples}

The sample is part of the number and characteristics possessed by the population. If the population is large, and it is impossible for the researcher to study everything in the population, for example because of limited funds, manpower, and time, the researcher can use a sample taken from that population. For this reason, samples taken from the population must be truly representative or representative (Sugiyono, 2007). The sample in this study were 42 employees.

\section{RESULTS AND DISCUSSION}

Internal consistency analysis is a form of reliability used to assess the consistency of results across items on the same test. Internal consistency testing using a composite reliability value with the criteria of a variable is said to be reliable if the composite reliability value is $>0.600$ (Hair, Hult, Ringle, \& Sarstedt, 2014).

\begin{tabular}{l|r|r|r|r} 
& Cronbach's Alpha & rho_A & Composite Reliability & Average Variance Extracted (AVE) \\
\hline ETOS KERIA & 0.728 & 0.739 & 0.880 & 0.785 \\
\hline KINERJA KARYAWAN & 0.952 & 0.962 & 0.976 & 0.954 \\
MOTIVASI KERJA & 0.748 & 0.887 & 0.854 & 0.670 \\
REWARDS & 0.794 & 0.805 & 0.906 & 0.828 \\
\hline
\end{tabular}

Source: Data Processing (2021)

Based on the results of the analysis in the image above, it is found that the variable X1 has a composite reliability of $0.854>0.600$, then the $\mathrm{X} 1$ variable is reliable, then the $\mathrm{X} 2$ variable gets the composite reliability with the results of $0.880>0.600$ then the $\mathrm{X} 2$ variable is reliable, the $\mathrm{X} 3$ variable gets the composite reliability results of $0.906>0.600$ then variable $\mathrm{X} 3$ is reliable, and variable $\mathrm{Y}$ with a composite reliability value of $0.976>0.600$ then $\mathrm{Y}$ is reliable.

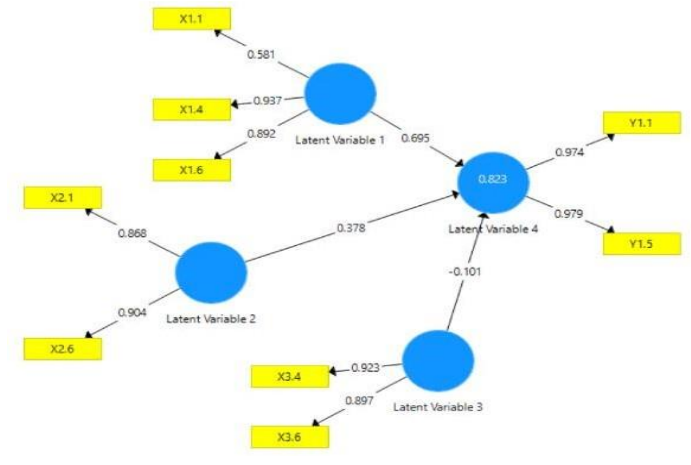


Hypothesis testing aims to prove the hypotheses of the effect of a variable on other variables directly (without intermediaries). If the path coefficient value is positive, it indicates that an increase in the value of one variable is followed by an increase in the value of another variable. if the path coefficient value is negative it indicates that an increase in one variable is followed by a decrease in the value of another variable. If the probability value (P-Value) <Alpha (0.05) then Ho is rejected (the effect of a variable with other variables is significant). If the probability value (PValue)> Alpha (0.05) then Ho is rejected (the effect of a variable with other variables is insignificant).

\begin{tabular}{|l|r|r|r|r|r|} 
& Original Sampl... & Sample Mean $(\ldots$ & Standard Devia... & T Statistics $(\mid \mathrm{O} / \ldots$ & P Values \\
\hline ETOS KERJA -> ... & 0.378 & 0.362 & 0.167 & 2.258 & 0.024 \\
\hline MOTIVASI KERJ... & 0.695 & 0.675 & 0.214 & 3.247 & 0.001 \\
\hline REWARDS $>>$ K... & -0.101 & -0.064 & 0.217 & 0.465 & 0.642 \\
\hline
\end{tabular}

Source: Data Processing (2021)

1. Variable X1 Work Motivation produces an original sample value of 0.695 with a $P$ value of $0.001<0.05$, so variable $\mathrm{X} 1$ has a positive and significant effect on variable $\mathrm{Y}$ employee performance.

2. The $\mathrm{X} 2$ variable work ethic produces an original sample value of 0.378 with a $\mathrm{P}$ value of $0.024<0.05$, so the $\mathrm{X} 2$ variable has a positive and significant effect on the employee performance variable $\mathrm{Y}$.

3. The $\mathrm{X} 3$ Rewards variable produces the original sample value of -0.101 with a $P$ value of $0.642<0.05$, so the $\mathrm{X} 3$ variable has a negative and insignificant effect on the employee performance variable $\mathrm{Y}$.

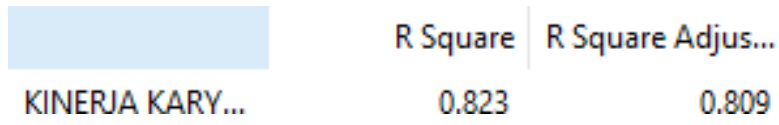

In the table above, the results show that the effect of $\mathrm{X} 1, \mathrm{X} 2$ and $\mathrm{X} 3$ on $\mathrm{Y}$ is 0.823 , meaning that the magnitude of the effect of $\mathrm{X} 1, \mathrm{X} 2$ and $\mathrm{X} 3$ on $\mathrm{Y}$ is $82.3 \%$.

\section{CONCLUSION}

1. The direct effect of Work Motivation (X1) on Employee Performance (Y) has a parameter coefficient of 0.695 (positive), so an increase in the value of Work Motivation (X1) will be followed by an increase in Employee Performance (Y) and $\mathrm{P}$ value of Work Motivation (X1) towards Employee performance (Y) is $0.024<0.005$ so it can be stated that the effect of work motivation on employee performance is significant.

2. The direct effect of Work Ethics (X2) on Employee Performance (Y) has a parameter coefficient of 0.378 (positive), so an increase in the value of Work Ethics (X2) will be followed by an increase in Employee Performance (Y) and P value of Work Ethics (X2) towards Employee Performance $(\mathrm{Y})$ is $0.001>0.05$, so it can be stated that the influence of Work Ethics on Employee Performance is significant.

3. The direct effect of Rewards (X3) on Employee Performance (Y) has a parameter coefficient of -0.101 (negative), so there is a negative effect where the less Rewards (X3) the lower the Employee Performance (Y) and P value Rewards (X3) on Employee Performance (Y) is -0.642> 0.05 so it can be stated that the effect of Rewards on Employee Performance is insignificant. 
THE EFFECT OF ORGANIZATIONAL CULTURE, QUALITY OF HUMAN RESOURCES, AND THE MOTIVATION TO THE EMPLOYEES PERFORMANCE IN THE CORRECTIONAL INSTITUTION CLASS IIA OF BATAM WITH THE WORK DISCIPLINE OF INTERVENING DOI: https://doi.org/10.54443/ijset.v1i2.14

4. The magnitude of the influence of Work Motivation (X1), Work Ethic (X2) and Rewards (X3) on Employee Performance (Y) is determined by the value of $r^{2}$, the value of $r^{2}$ on job satisfaction (Y) is 0.823 which means the influence of Work Motivation (X1), Work Ethic (X2) and Rewards (X3) on Employee Performance (Y) amounted to 82.3\%.

\section{REFERENCES}

Agoes, S. 2008. Auditing (Pemeriksaan Akuntansi) oleh Kantor Akuntan Publik.Edisi ketiga cetakan keempat.Lembaga Penerbitan Fakultas Ekonomi Universitas Jakarta.Jakarta.

Arens, A.A., J.K. Loebbecke. 2000. Auditing: An Integrated Approach. Eight Edition. New Jersey: Prentice Hall International Inc.

Atmawinata, Susilawati.2014. "Pengaruh Profesionalisme Dan Independensi Auditor Internal Terhadap Kualitas Audit: Studi Pada Inspektorat Propinsi Jawa Barat” Jurnal Etikonomi . STIE STEMBI. Vol. 13 No. 2 Oktober 2014

De Angelo, L.E. 1981. Auditor Size and Audit Quality. Journal of Accounting and Economic 3, pp: 183-199

Efendy. (2010). "Pengaruh Kompetensi, Independensi dan Motivasi auditor terhadap Kualitas Audit Inspektorat dalam Pengawasan Keuangan Daerah" (Studi Empiris pada Pemerintah Kota Gorontalo). Universitas Dipenogoro.

Ghozali, Imam (2011), Aplikasi Analisis Multivariate Dengan Program SPSS, Semarang: Badan Penerbit Universitas Diponegoro.

Ilham, R. N., Sadalia, I., Irawati, N., \& Sinta, I. (2022). Risk And Return Model of Digital Cryptocurrency Asset Investment In Indonesia. Al Qalam: Jurnal Ilmiah Keagamaan dan Kemasyarakatan, 16(1), 357-376.

Natawirani, Putu dan I Gde Ary. 2017. "Pengaruh Kompleksitas Tugas, Independensi Dan Komitmen Profesional Pada Kualitas Audit”. E-Jurnal Akuntansi Universitas Udayana. Vol.18.1. Januari (2017): 735-762

Rumengan Jemmy, 2013. Metodologi Penelitian. Bandung : Citapustaka Media Perintis Suardinatha, Made dan Made G Wirakusuma.2016. "Pengaruh Independensi Dan

Profesionalisme Terhadap Kualitas Audit Dengan Kepuasan Kerja Sebagai Variabel Pemoderasi”. E-Jurnal Akuntansi Universitas Udayana. Vol.17.3. Desember (2016)

Sinurat, M., Ilham, R. N., \& Cen, C. C. (2021, February). Asetpedia. id as a Start-Up Based Technology Benchmarking Innovation for Beginning Companies in the North Sumatera Region. In International Conference on Strategic Issues of Economics, Business and, Education (ICoSIEBE 2020) (pp. 109-114). Atlantis Press.

Sugiyono. 2008. Metode Penelitian Kuantitatif, Kualitatif, dan R\&D. Penerbit Alfabeta. Bandung.

Sugiyono. 2014. Metode Penelitian Kuantitatif Kualitatif dan R\&D. Bandung : CV. Alfabeta Alfabeta

Wadji, Andi. 2013. "Pengaruh Profesionalisme, Indenpendensi Auditor Dan Kompleksitas Tugas Terhadap Kualitas Audit Dengan Pendidikan Dan Pelatihan Audit Sebagai Variabel Moderasi”. Jurnal Informasi Perpajakan, Akuntansi Dan Keuangan Publik. Vol.8 No.2 Juli 2013. Hal : $87-10$ 